\title{
Research Status and Prospect of Friction Stir Processing Technology
}

\author{
Kan Li, Xuemei Liu * and Yi Zhao
}

Key Laboratory for Liquid-Solid Structural Evolution and Processing of Materials Ministry of Education, Shandong University, Jinan 250061, China; 201813754@mail.sdu.edu.cn (K.L.); 201612599@mail.sdu.edu.cn (Y.Z.)

* Correspondence: xuemei_buaa@sdu.edu.cn; Tel.: +86-531-8839-2208

Received: 31 December 2018; Accepted: 16 February 2019; Published: 19 February 2019

\begin{abstract}
Friction stir processing (FSP) is a novel solid-phase processing technique that is derived from friction stir welding (FSW). The microstructure of the base metal can be modified with the friction heat and stir function during processing. It can be used to fabricate surface composites and in situ composites by adding reinforced particles into the metal matrix via FSP. Friction stir processing can significantly improve the hardness, wear resistance, ductility, etc., while preventing defects caused by material melting. It is an ideal material processing technology and has good prospects in the field of superplastic materials and for the preparation of metal matrix composites. This paper reviews research developments into the principle, process, and applications of FSP technology as well as its future research directions and development prospects.
\end{abstract}

Keywords: friction stir processing; surface composites; in-situ composites; superplastic materials

\section{Introduction}

Friction stir processing (FSP) is derived from friction stir welding (FSW). It is a novel material-processing technology proposed by Mishra [1] in 1999 which was originally used in the preparation of superplastic materials. Friction stir processing and FSW have similar processes and principles. Both of them make the material undergo severe plastic deformation leading to a homogeneous refined microstructure via friction heat and stirring during processing [2]. As a solid-state processing method, there is no melting of materials during FSP. This effectively avoids defects such as porosities and thermal cracks that are generated during the melting and solidification of materials. Solid-state processing also reduces the dilution rate of materials and significantly improves the microstructure and properties of the base metal. Researchers have used FSP for material modification and the fabrication of metal matrix composites. Friction stir processing has many advantages over traditional material processing technologies especially relative to low-melting non-ferrous materials that are difficult to process. In the 20 years, FSP technology has been extensively studied and has evolved into many new application directions including superplastic materials and surface composites. This paper reviews the principles, processes, and applications of FSP technology as well as its future directions and development prospects.

\section{Principle}

\subsection{Process Principle}

The process principle of FSP is shown in Figure 1. Friction stir processing can be implemented on conventional FSW machines. The base metal is processed via a non-consumable rotating tool with a pin and a shoulder. During FSP, the tool rotates at high speed and plunges into the workpiece under axial force until the shoulder contacts the surface of the workpiece leading to friction. The tool then 
traverses relative to the workpiece along the processing direction. Significant heat is generated via friction between the shoulder and the workpiece. The base metal in the processing region softens when the temperature rises under the action of friction heat leading to intense plastic deformation with rotation and movement of the pin. Finally, the material is remolded via plastic material flow [3].

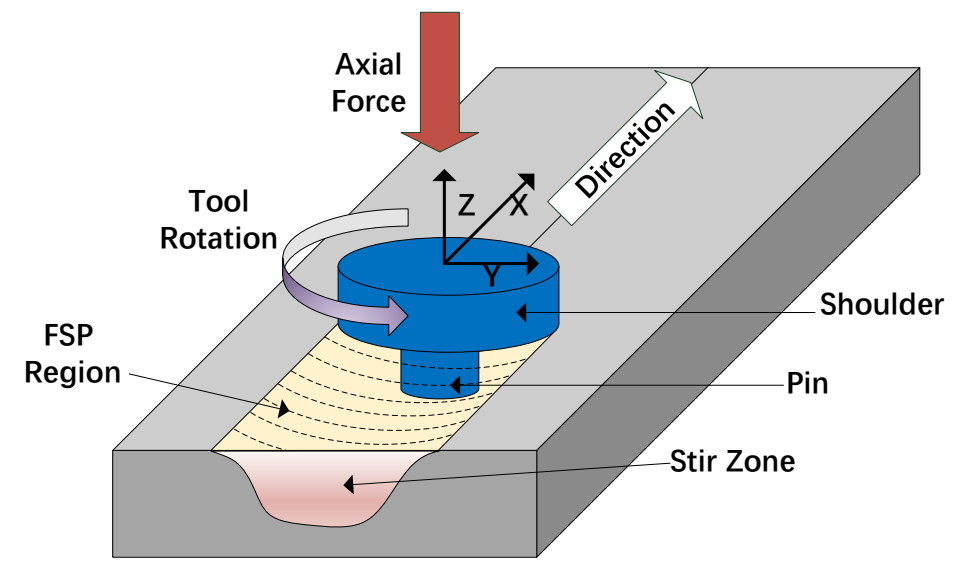

Figure 1. Schematic diagram of friction stir processing (FSP).

\subsection{Microstructure Transformation during Friction Stir Processing (FSP)}

The microstructure transformation during FSP is due to thermal-mechanical effects. Similar to FSW, the processing region obtained by FSP is usually divided into a stir zone (SZ), thermo-mechanically affected zone (TMAZ), heat-affected zone (HAZ), and base metal zone (BM) $[4,5]$. The SZ mainly consists of homogeneous refined equiaxed grains whose sizes are decreased several times compared to the base metal. During the FSP process, SZ experiences a high peak temperature and severe plastic deformation-this leads to microstructure evolution due to dynamic recrystallization [6-8]. The proportion of high-angle grain boundaries (HAGBs) in the processing region is increased after FSP [9], which promotes grain boundary slippage resulting in an obvious improvement in the plasticity of the base metal [10]. A typical onion ring pattern is seen in SZ due to the flow of the plastic material layer from the front of the tool to the back of the tool. This can characterize the flow of the material [11]. The TMAZ is affected by thermal cycling and mechanical stirring where grain deformation and partial recrystallization occur. Dissolution of the precipitate phase is observed in this area [12].

When reinforcing particles are added to the metal matrix, particle-stimulated nucleation favors the formation of grains during recrystallization. According to the Zener-Hollomon mechanism, the uniformly distributed fine particles can inhibit grain growth during the dynamic recrystallization process. This occurs via the pinning action on the grain boundaries resulting in a significant refinement of the microstructure [13].

\section{Process}

\subsection{Influence of Process Parameters}

The main process parameters of FSP include the tool rotation speed, tool traverse speed, tool tilt angle, and multi-pass times. The geometry and size of the tool also have a large impact on material formation.

The rotation speed and traverse speed of the tool are the most important parameters-they can control the heat input and the flow of the plastic material during FSP. This makes a remarkable influence of the microstructure and properties of the processed material. There is more heat generation with a high rotation speed and low traverse speed-this can lead to a larger processed region [14,15]. At a lower ratio of rotation speed to traverse speed, the heat input decreases refining the microstructure 
and increasing the hardness [16-18]. A lower traverse speed in multi-pass FSP can inhibit abnormal grain growth [19]. When the composites are fabricated via FSP, increased heat input and more plastic deformation are caused by the higher rotation speed or lower traverse speed [20]. These features are beneficial to the mixture of reinforced particles and the matrix. Longer heat exposure time can promote the in situ reaction resulting in more strengthening phases forming in the in situ reaction with homogeneous distribution in the matrix. All of these steps improve the properties of the composites [21-23]. In addition, the higher ratio of rotation speed to traverse speed decreases the dislocation density. As a result, the electrical conductivity of the processed copper increases [24].

During FSW, a small tool tilt angle can form a less-defect processed region via increased axial impact loading and material flow [25]. Many FSP researchers have drawn on this concept to make the reinforced particles distribute in the matrix more uniformly $[6,12,26,27]$. The tool tilt angle in FSP process is usually less than $5^{\circ}$.

Increasing pass times and changing direction of tool rotation between the two passes can improve the plastic deformation of the processed materials. Hence, the grain refinement and improvement in materials properties are more significant [28]. Multi-pass FSP has been widely used in the production of composites. Compared with single-pass FSP, composites fabricated via multi-pass FSP have a more homogeneous strengthening phase distribution, and in situ reactions during the FSP propagate more thoroughly [29-32].

\subsection{Influence of Tool Geometry}

The non-consumable stir tool used in the FSP processes can be divided into two categories: tools with pins and pin-less tools (Figure 2). Of these, tools with pins are used more widely, and pin-less tools are usually utilized for modifying material surfaces [33] or encapsulating reinforced particles during composite processing $[17,21,31,34-40]$.

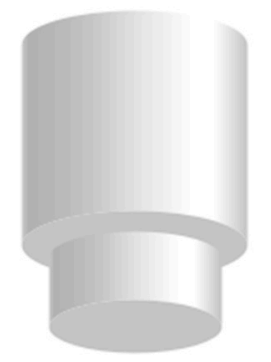

(a)

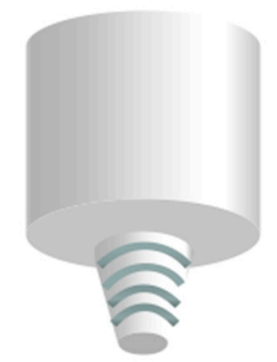

(b)

Figure 2. Two common kinds of stir tools: (a) pin-less and (b) with pin.

The size of the tool and the shape of the pin have a large effect on the heat production and material flow during FSP processing. When a tool with a larger shoulder diameter is used, the friction heat is more concentrated, and the material plastic deformation is more severe. This results in a stable microstructure and a better refinement of second phase particles [41]. Studies on the influence of pin profiles on heat generation during the plunge stage show that an effective tool pin area plays a key role in the friction deformation and heat production; hence, the temperature during the plunge stage is lowest with the use of a conical pin [42].

Mahmoud et al. [34] compared the effects of four different pin shapes on SiC-reinforced composites on the $\mathrm{Al}$ surface (Figure 3). The results showed that the average size of the $\mathrm{SiC}$ particles was the smallest and the distribution of SiC particles was the most homogeneous in $\mathrm{SZ}$ with a square pin. As a result, the matrix grains in SZ were obviously finer, and the hardness of the surface composite increased markedly compared with the matrix. However, the tools with square and triangular pins wore faster than those with circular pins. 


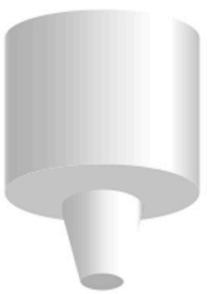

(a)

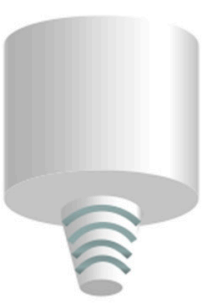

(b)

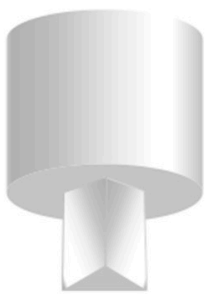

(c)

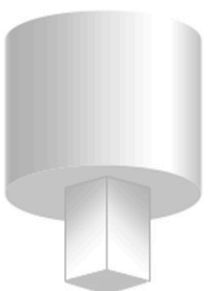

(d)

Figure 3. Different shapes of pin: (a) circular; (b) circular with thread; (c) triangular; and (d) square.

\subsection{Method of Adding Reinforced Particles}

Researchers have tried many methods to add reinforced particles into the metal matrix during FSP. Mishra et al. [43] added a small amount of methanol into SiC powders, mixed them well, and then smeared the mixture on the surface of the workpiece to fabricate thin surface composites with FSP. However, the particles added in this way are easy to slip and splash during the FSP process; hence, there is an inhomogeneous distribution of the strengthening phases and a loss of material. Based on this method, pre-fabricated surface composites can be fabricated by cold spraying $[44,45]$ or laser melting [46] with further processing of the coating via FSP. This can improve the microstructure and the distribution of the reinforced particles to obtain surface composites with better properties.

A common method to fabricate surface composites is to pre-manufacture grooves on the surface of plates and then fill them with reinforced particles (Figure 4a). The grooves are then capped with a pin-less tool via FSP-this prevents the particles from splashing. Subsequently, the tool with a pin is used in the multi-pass FSP process along with pre-manufactured grooves; thus, the reinforced particles are uniformly distributed with material flow $[17,21,31,34-40]$. In addition, the surface composites with a homogeneous distribution of strengthening phases were also obtained by adding reinforced particles after drilling blind holes on the surface of the workpieces [39,47,48] (Figure $4 b$ ).

Huang et al. [49] used a hollow pin-less tool in the study of in situ fabrication of Mg surface composites via FSP (Figure 5). During this process, the reinforced particles were continuously added to the surface of the substrate via the feeding passage in the middle of the tool. These were well-mixed with the matrix under pressing and stirring action of the shoulder. This prevented particle splashing during the FSP process.

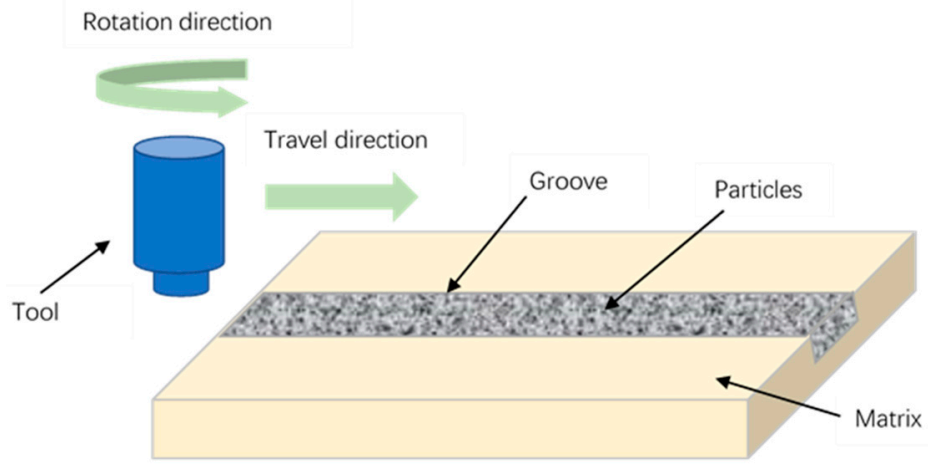

(a)

Figure 4. Cont. 


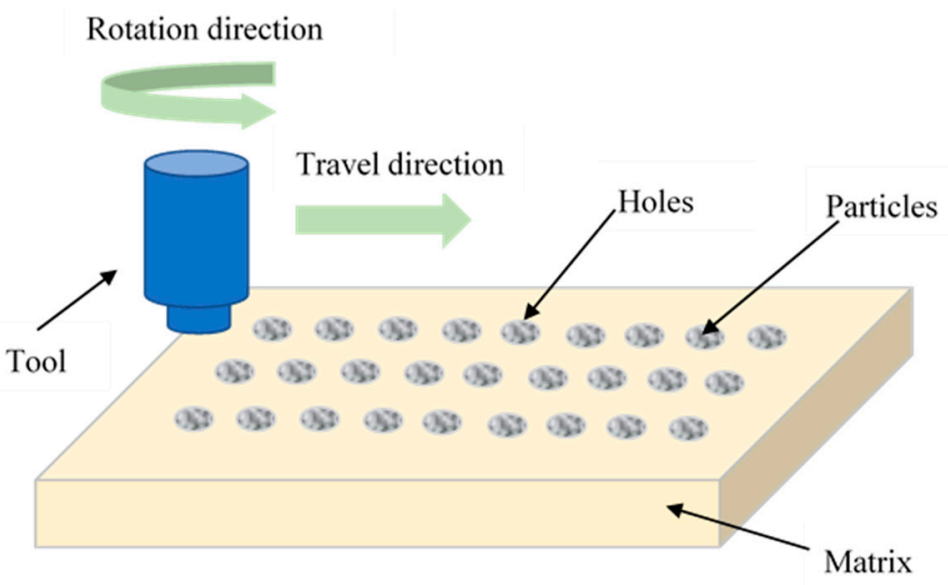

(b)

Figure 4. Adding particles methods of fabricating the surface composites: (a) groove; (b) holes.
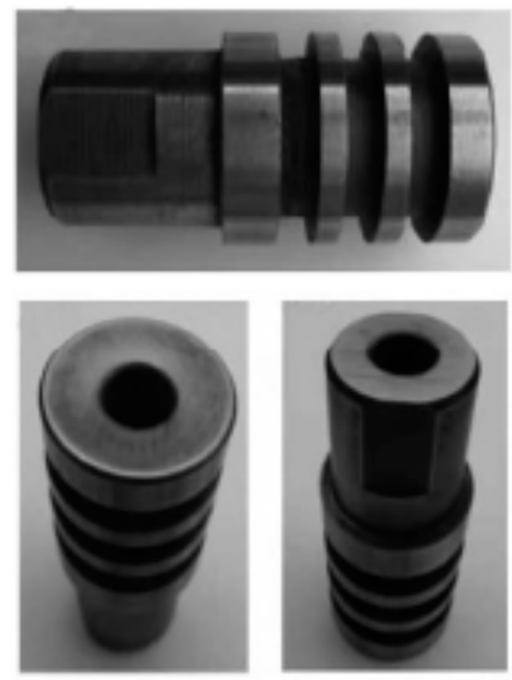

Figure 5. A novel hollow pin-less tool. (Reprinted with permission from [49]. Copyright 2013 Transactions of The China Welding Institution).

\section{Applications}

\subsection{Material Modification}

\subsubsection{Microstructure Improvement of Casting Materials}

Defects such as porosity and shrinkage in the interior of the cast metal as well as a coarse, dendritic structure can make it difficult to characterize metal's properties. With FSP technology, casting defects can be eliminated and coarse dendrites can be broken. The dynamic recrystallization leads to a remarkable refinement of the grains; thus, the microstructure and properties of as-cast materials are improved.

Sekban et al. [50] obtained a 4-mm thick strengthening layer on the surface of low carbon steel via FSP, whose hardness and strength increased due to the microstructural refinement. As a result, wear resistance improved. Tinubu et al. [51] compared the wear resistance of A-286 stainless steel under rolled and aged and FSP and aged conditions. It was found that grains of A-286 stainless steel obtained by FSP processing were refined, which led to increases in microhardness and strength in the stir zone, and abrasive wear debris were smaller and decreased when compared with the rolled and aged alloy, hence the wear rate was significantly reduced. By comparison, FSP could be considered as an effective surface engineering technique to improve the wear resistance of stainless steel. 
Wang et al. [8] studied improvements in the microstructure and mechanical properties of an $\mathrm{Mg}-\mathrm{Zn}-\mathrm{Y}-\mathrm{Zr}$ alloy via FSP. The base metal was characterized as a typical cast structure consisting of coarse grains and intergranular eutectic networks mainly composed of an I-phase. During the FSP process, coarse grains, and eutectic networks were broken into fine particles and uniformly distributed. The I-phase was converted into the $\mathrm{W}$-phase. The SZ grains were significantly refined because of the dynamic recrystallization and pinning effects of the dispersed particles; hence, this system led to much better mechanical properties for the FSPed samples relative to the base metal.

Pang et al. [52] performed FSP on AA7075-T6 plates in both air and underwater environments. The grain refinement was obvious, and the $\mathrm{Al}_{7} \mathrm{Cu}_{2} \mathrm{Fe}$ phase (which can easily cause pitting) was broken or dissolved into the matrix during the FSP process. Thus, the processed samples had good mechanical properties and corrosion resistance. In the underwater FSP, the grain size was reduced more because of the higher cooling rate. However, rapid cooling prevented the diffusion of elements so that $\mathrm{Zn}$ and $\mathrm{Cu}$ accumulated on the surface of the plates; hence, the $\mathrm{Cu}$ acted as a cathode to accelerate the electrochemical corrosion of the $\mathrm{Al}$ matrix. Therefore, the corrosion resistance in the more aggressive environment of the underwater FSPed samples was not as good as that of samples processed by in-air FSP. This study comprehensively analyzed the effects of FSP on several different corrosion resistance of aluminum alloys and confirmed the feasibility of underwater FSP.

\subsubsection{Preparation of Superplastic Materials}

Superplasticity implies that a material has high elongation without necking when the material is stretched under specific conditions. This is generally defined as a material whose elongation is $>500 \%$ can be identified as a superplastic material. It is generally believed that a grain size of less than $10 \mu \mathrm{m}$ is a prerequisite for obtaining superplasticity [53]. Superplastic materials are easily processed into complex parts, which is important for material formation. Traditional superplastic material processing methods have complicated procedures and low production efficiency. Materials with relatively coarse grains obtained via these methods only exhibit superplasticity at higher temperatures. Superplasticity is due to the operation of the grain boundary sliding (GBS) mechanism. Therefore, the smaller the grain size, and the higher the average misorientation, usually, the larger the elongation, the higher the superplastic strain rate, the lower the flow stress, and the lower the feasible temperature for superplasticity $[20,54,55]$. Superplastic materials obtained by FSP are usually with refinement grains, which can achieve low temperature superplasticity. Some superplastic materials fabricated via FSP are listed in Table 1.

Mishra et al. [1] utilized FSP technology to achieve high strain rate superplasticity for $7075 \mathrm{Al}$ alloy. The average grain size of the FSPed $7075 \mathrm{Al}$ alloy was $3.3 \pm 0.4 \mu \mathrm{m}$, and the best superplasticity (elongation was over $1000 \%$ ) was obtained at a strain rate of $1 \times 10^{-2} \mathrm{~s}^{-1}$ and $490^{\circ} \mathrm{C}$. This was the first application of FSP in the preparation of superplastic materials, which was of great significance in the research field of superplastic materials. At the same time, it also promoted the development of FSP technology.

Yang et al. [10] realized high strain rate superplasticity of $\mathrm{Mg}-\mathrm{Zn}-\mathrm{Y}-\mathrm{Zr}$ alloy by FSP, and the elongation reached $1110 \%$ at $450{ }^{\circ} \mathrm{C}$ and $1 \times 10^{-2} \mathrm{~s}^{-1}$. The Mg alloys have poor thermal stability; thus, it is difficult to achieve high strain rate superplasticity even if the grain size is less than $1 \mu \mathrm{m}$. The I-phase and the $\mathrm{W}$-phase in the $\mathrm{Mg}-\mathrm{Zn}-\mathrm{Y}-\mathrm{Zr}$ alloy can improve the thermal stability of the alloy. The microstructure of the alloy after FSP was dominated by equiaxed grains with an average grain size of $4.5 \mu \mathrm{m}$ and a HAGBs fraction of $91 \%$. With the stirring and crushing features of FSP, the W-phase particles were remarkably refined and uniformly distributed in the matrix. The quasicrystal I-phase with a lower eutectic temperature disappeared. The relatively large grains and uniformly distributed W-phase gave the alloy better thermal stability, and the dominant HAGBs contributed to the grain boundary sliding. Thus, this material has a high strain rate superplasticity.

Zhang et al. [56] processed Ti-6Al-4V alloy by FSP to obtain an $\alpha+\beta$ dual-phase structure. The $\alpha$-phase had equiaxed grains with an average size of $0.51 \mu \mathrm{m}$. These were obtained via 
dynamic re-crystallization during FSP, and the proportion of HAGBs with random orientations was high. A small amount of $\beta$-phase was distributed at the grain boundaries of the $\alpha$-phase-this $\beta$-phase had a "lubricating" function and improved grain boundary sliding giving the alloy low temperature superplasticity. The elongation of most tensile specimens tested under different conditions exceeded $400 \%$, and the maximum elongation was $1130 \%$ at $600{ }^{\circ} \mathrm{C}$; the strain rate was $3 \times 10^{-4} \mathrm{~s}^{-1}$. The successful fabrication of low temperature superplastic materials had far-reaching effects on the application of titanium alloy superplastic materials.

Table 1. Superplastic materials obtained via FSP.

\begin{tabular}{ccccc}
\hline Materials & $\begin{array}{c}\text { Maximum } \\
\text { Elongation }\end{array}$ & Temperature & Strain Rate & Reference \\
\hline AA7075 & $1000 \%$ & $490^{\circ} \mathrm{C}$ & $1 \times 10^{-2} \mathrm{~s}^{-1}$ & Mishra et al. [1] \\
AA2024 & $525 \%$ & $430^{\circ} \mathrm{C}$ & $1 \times 10^{-2} \mathrm{~s}^{-1}$ & Charit et al. [57] \\
Cast A356 & $650 \%$ & $530^{\circ} \mathrm{C}$ & $1 \times 10^{-3} \mathrm{~s}^{-1}$ & Ma et al. [58] \\
AA7075 & $1255 \%$ & $470^{\circ} \mathrm{C}$ & $1 \times 10^{-2} \mathrm{~s}^{-1}$ & Johannes et al. [59] \\
Al-4Mg-1Zr & $1400 \%$ & $425^{\circ} \mathrm{C}$ & $1 \mathrm{~s}^{-1}$ & Ma et al. [60] \\
ZK60 & $1800 \%$ & $325^{\circ} \mathrm{C}$ & $1 \times 10^{-3} \mathrm{~s}^{-1}$ & Xie et al. [61] \\
Mg-Zn-Y-Zr & $1110 \%$ & $450^{\circ} \mathrm{C}$ & $1 \times 10^{-2} \mathrm{~s}^{-1}$ & Yang et al. [10] \\
AZ91 & $990 \%$ & $350^{\circ} \mathrm{C}$ & $2 \times 10^{-2} \mathrm{~s}^{-1}$ & Chai et al. [62] \\
AA6063-T6 & $225 \%$ & $344^{\circ} \mathrm{C}$ & $1 \times 10^{-2} \mathrm{~s}^{-1}$ & Karthikeyan et al. [63] \\
Mg-Y-Nd & $967 \%$ & $500^{\circ} \mathrm{C}$ & $3 \times 10^{-3} \mathrm{~s}^{-1}$ & Cao et al. [64] \\
ZrB2/2024Al composites & $292.5 \%$ & $477^{\circ} \mathrm{C}$ & $5 \times 10^{-3} \mathrm{~s}^{-1}$ & Zhao et al. [65] \\
AA7075 & $550 \%$ & $220-3800^{\circ} \mathrm{C}$ & $1 \times 10^{-2} \mathrm{~s}^{-1}$ & Orozco-Caballero et al. [66] \\
Al3Zr/6063Al composites & $330 \%$ & $500^{\circ} \mathrm{C}$ & $1 \times 10^{-2} \mathrm{~s}^{-1}$ & Yang et al. [67] \\
Al3Ti/2024Al composites & $642 \%$ & $510^{\circ} \mathrm{C}$ & $0.15 \mathrm{~s}^{-1}$ & Jiao et al. [68] \\
Ti-6Al-4V & $1130 \%$ & $600^{\circ} \mathrm{C}$ & $3 \times 10^{-4} \mathrm{~s}^{-1}$ & Zhang et al. [56] \\
\hline
\end{tabular}

\subsection{Fabrication of Metal Matrix Composites}

\subsubsection{Fabrication of Surface Composites via Reinforced Particles}

Metal matrix composites have high hardness, high strength, high modulus of elasticity, etc. To improve the surface properties of these materials, surface composites are often fabricated by techniques such as laser cladding and plasma spraying. However, these methods all involve material melting-usually accompanied by defects such as porosity and hot cracking. The reinforcing particles are easily burned at high temperature. Grains and the second phases in the coating structure are relatively coarse. Using FSP technology, surface nanocomposites with a uniformly distributed strengthening phase can be obtained under solid-state conditions. This effectively avoids burning of the strengthening phase and the formation of harmful phases. There are many kinds of reinforced particles commonly added to the FSP process including $\mathrm{SiC}[13,43], \mathrm{B}_{4} \mathrm{C}$ [39,47,48], GNPs [30], CNTs [37], and $\mathrm{Al}_{2} \mathrm{O}_{3}$ [45], etc., shown in Table 2 .

Mishra et al. [43] smeared a layer of $\mathrm{SiC}$ powder on the surface of $5083 \mathrm{Al}$ alloy plate and obtained $\mathrm{Al} / \mathrm{SiC}$ composite coatings of 50-200 $\mu \mathrm{m}$ via FSP. The surface composite layers were well bonded to the substrate and their hardness was doubled compared to the substrate. This work demonstrated the feasibility of FSP in the fabrication of surface composites. However, the process of adding reinforcing particles by smearing was not mature enough and was gradually replaced by other processes.

Khodabakhshi et al. [13] applied a multi-pass FSP to fabricate ultra-fine-grained Al-Mg-SiC nanocomposites. The SZ microstructure was fine equiaxed recrystallized grains, and the $\mathrm{SiC}$ particles were homogeneously distributed in the matrix and bonded well with the matrix. Due to the particle-stimulated nucleation and the Zener-Hollomon mechanism during dynamic recrystallization, the average grain size decreased from 6.3 to $1.4 \mu \mathrm{m}$, and the dislocation density increased. As a result, the hardness of the composite increased from 51.5 to $123 \mathrm{HV}$ compared with the base metal. For slight changes in plasticity, the yield strength and ultimate tensile strength were remarkably improved, and the fracture mechanisms were shown as a combined ductile-brittle fracture behavior. Further study indicated that the grain boundary strengthening was the main strengthening mechanism of this 
nanocomposite. The performance of the surface composites prepared by the FSP technique was more excellent and the process was more mature.

Reddy et al. [47] fabricated a $\mathrm{B}_{4} \mathrm{C}$-reinforced composite coating on the surface of a Ti-6Al-4V alloy plate via FSP. The wear resistance improved over 134 times compared with the base metal, but the hardness of the coating was only doubled. This was even better than mild steel and austenitic stainless steel. The presence of hard $\mathrm{B}_{4} \mathrm{C}$ particles greatly reduced the direct wear of the matrix; hence, the wear mechanism transformed from abrasion to adhesion, and the average friction coefficient was reduced from 0.20 to 0.06 . But the process of adding reinforced particles through blind holes was relatively cumbersome and had not been extended to more applications.

Table 2. Surface composites fabricated via FSP.

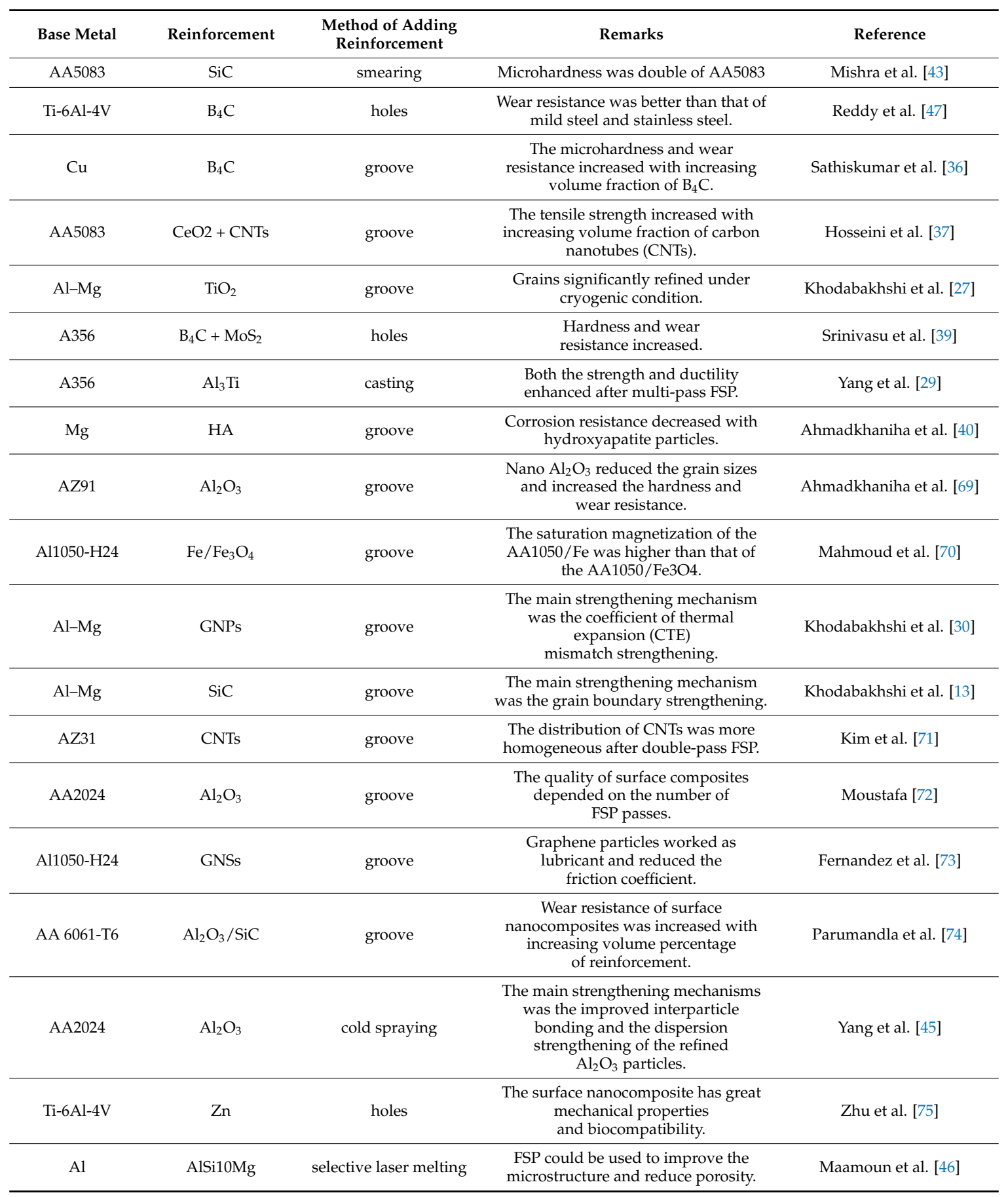


Hosseini et al. [37] used an Al5083 alloy as the matrix material, $\mathrm{CeO}_{2}$ and carbon nanotubes (CNTs) as the strengthening phase, and obtained the surface hybrid composites via multi-pass FSP. Many $\mathrm{CeO}_{2} / \mathrm{Al} 5083$, CNTs / $\mathrm{Al} 5083$, and $\mathrm{CeO}_{2} / \mathrm{CNTs} / \mathrm{Al} 5083$ composite modes were evaluated by changing the volume ratio of $\mathrm{CeO}_{2}$ and CNTs. The results showed that the performance of several different proportions of surface composites was significantly improved. The impact of CNTs on the strength of the matrix was larger than that of $\mathrm{CeO}_{2}$. The tensile strength increased with increasing volume fraction of CNTs. When the ratio of CNTs to $\mathrm{CeO}_{2}$ was $75: 25$, the hybrid composite had the best performance: The ultimate tensile strength reached $396 \mathrm{MPa}$, and the hardness was $173 \mathrm{VHN}$. These were $42 \%$ and $118 \%$ higher than that of the base metal. And the addition of $\mathrm{CeO}_{2}$ could improve the pitting resistance considering the corrosion performance. However, CNTs as a cathode in the corrosion galvanic cell reduced the corrosion resistance of the $\mathrm{Al}$ matrix. As we have seen, more and more reinforced particles were used in FSPed surface composites.

\subsubsection{Fabrication of In Situ Composites}

The concept of in situ composition is derived from in situ crystallization and in situ polymerization. The strengthening phases were obtained from the in situ reaction during material formation rather than direct addition from the outside world. Therefore, compared with the conventional composite material, the second phases of the in situ composites can achieve a smaller size and a more uniform distribution. This makes it easier to add nanometer-sized strengthening phases into the matrix. They also offer better interfacial bonding with the matrix because the second phases are directly generated in the matrix via an in situ reaction [76]. As a solid-phase material processing method, FSP is a reliable technology for fabricating in situ composites. Severe plastic deformation of the matrix material during FSP causes the constituent phases to mix and refine; the frictional heat and the deformation heat increase the reaction temperature to promote the formation of intermetallic compounds. Existing in situ composite combinations obtained via FSP include Al-Cu [77], $\mathrm{Al}-\mathrm{Ti}$ [78], $\mathrm{Al}-\mathrm{Ni}$ [23,78], $\mathrm{Al}-\mathrm{Nb}$ [31], $\mathrm{Al}-\mathrm{CuO}$ [79], and $\mathrm{Al}-\mathrm{Mg}-\mathrm{CuO}$ [80], etc., shown in Table 3.

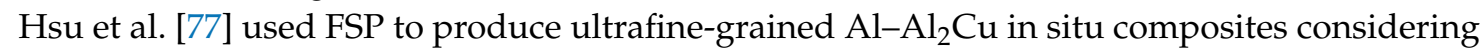
the hot processing properties of FSP. The $85 \%$ pure $\mathrm{Al}$ and $15 \%$ pure $\mathrm{Cu}$ powders were mixed and cold compacted to a billet. After sintering and $\mathrm{FSP}$, the $\mathrm{Cu}$ was completely reacted to form $\mathrm{Al}_{2} \mathrm{Cu}$ that was uniformly distributed in the $\mathrm{Al}$ matrix. The $\mathrm{SZ}$ grains were refined to 1-2 $\mu \mathrm{m}$, and the composites exhibited a high Young's modulus and good compressive properties. This study successfully applied FSP to the fabrication of in situ composites, which was important for the application of FSP in fabrication of composites.

You et al. [79] fabricated $\mathrm{Al}-\mathrm{CuO}$ in situ composites with a similar process, and two strengthening phases of $\mathrm{Al}_{2} \mathrm{O}_{3}$ and $\mathrm{Al}_{2} \mathrm{Cu}_{3}$ were produced in the FSP process. In the previous study, some $\mathrm{Al}_{2} \mathrm{Cu}_{3}$ particles were generated during the sintering process and refined to a micron size via the crushing action of FSP. Here, $\mathrm{CuO}$ was partially reduced to $\mathrm{Cu}_{2} \mathrm{O}$ after sintering, and $\mathrm{Al}_{2} \mathrm{Cu}_{3}$ particles with an average size of $100 \mathrm{~nm}$ were all formed in the FSP process. This can better strengthen the composite. The reaction simultaneously produced amorphous $\mathrm{Al}_{2} \mathrm{O}_{3}$ nanoparticles distributed in the matrix in the form of clusters. Compared with previous work, the process in this study was more suitable for the processing of in situ composites.

Zeidabadi et al. [31] studied the effect of $\mathrm{Nb}$ content and FSP pass number on the microstructure and properties of $\mathrm{Al}-\mathrm{Nb}$ in situ composites. During the FSP process, finer $\mathrm{Nb}$ particles could react with the $\mathrm{Al}$ matrix to form the $\mathrm{Al}_{3} \mathrm{Nb}$; for coarser $\mathrm{Nb}$ particles, the $\mathrm{Al}-\mathrm{Nb}$ reaction could only occur on its surface and form an $\mathrm{Al}_{3} \mathrm{Nb}$ shell to prevent continued propagation of the reaction. Some of the coarse $\mathrm{Nb}$ particles would be smashed during the plastic deformation process and transform into smaller round intermetallic particles. As the pass number increased, a high strain rate and severe plastic deformation produced more deformation heat and accumulated strains leading to a fuller in situ reaction. The $\mathrm{Al}_{3} \mathrm{Nb}$ distributed more homogeneously in the matrix. This helped improve the hardness and tensile strength. The performance test results showed that a higher $\mathrm{Nb}$ powder content 
led to better mechanical properties for the composites. The study used FSP technology to directly prepare in situ composite materials, eliminating the need for cold compacting and sintering processes, making it more convenient and energy efficient.

Table 3. In situ composites fabricated via FSP.

\begin{tabular}{|c|c|c|c|c|}
\hline Matrix & Additives & $\begin{array}{c}\text { Method of } \\
\text { Adding Additives }\end{array}$ & $\begin{array}{c}\text { Intermetallic } \\
\text { Phases }\end{array}$ & Reference \\
\hline $\mathrm{Al}$ & $\mathrm{Cu}$ & sintering & $\mathrm{Al}_{2} \mathrm{Cu}$ & Hsu et al. [77] \\
\hline $\mathrm{Al}$ & $\mathrm{Ti}$ & sintering & $\mathrm{Al}_{3} \mathrm{Ti}$ & Hsu et al. [81] \\
\hline Al1100-H14 & $\mathrm{Ni}$ & groove & $\mathrm{Al}_{3} \mathrm{Ni}$ & Qian et al. [78] \\
\hline $\mathrm{Al}$ & $\mathrm{Mg}+\mathrm{CuO}$ & cold compacting & $\mathrm{MgO}+\mathrm{Al}_{2} \mathrm{Cu}$ & You et al. [80] \\
\hline $\mathrm{Al}$ & $\mathrm{CuO}$ & sintering & $\mathrm{Al}_{2} \mathrm{O}_{3}+\mathrm{Al}_{2} \mathrm{Cu}$ & You et al. [79] \\
\hline $\mathrm{Al}$ & $\mathrm{TiO} 2$ + graphite & groove & $\mathrm{Ti}_{3} \mathrm{AlC}_{2}+\mathrm{TiC}$ & Madhu et al. [82] \\
\hline AA7075 & $\mathrm{K}_{2} \mathrm{TiF}_{6}+\mathrm{KBF}_{4}$ & casting & $\mathrm{TiB}_{2}$ & Rajan et al. [83] \\
\hline AA2024 & $\mathrm{K}_{2} \mathrm{ZrF}_{6}+\mathrm{KBF}_{4}$ & casting & $\mathrm{ZrB}_{2}$ & Zhao et al. [65] \\
\hline Al1050 & $\mathrm{Nb}$ & groove & $\mathrm{Al}_{3} \mathrm{Nb}$ & Zeidabadi et al. [31] \\
\hline
\end{tabular}

\section{Summary and Outlook}

As a novel material-processing technology, FSP has great application value in modification of materials and surface composite fabrication due to its special solid-phase processing mechanism. Compared with traditional composites processing methods, FSP has unique advantages and can be widely applied in the future. The feasibility of FSP has been demonstrated extensively via experiments, but the current process is not sufficiently mature. The next steps in FSP research include improving the process and solving practical application problems. The following problems need to be solved to achieve broad FSP applications:

- More complete theoretical support and process standards are needed. Most fabrications are only in the feasibility stage. Practical applications require a stable and reliable process. Mathematical physics models can explain the mechanism of FSP, and the use of parameter optimization systems can help us formulate suitable processes.

- The process of composite fabrication should be improved. It is difficult to obtain complete and uniform composite materials through existing reinforcement phase addition methods-regardless of fabricating surface composites or bulk composites. These processes are too cumbersome to practically deploy.

- The wear of stir tools also limits industrial applications of FSP. Although the tools used in FSP are, in principle, non-consumable, they do experience severe wear during this process. Frequent tool replacement not only affects efficiency but also increases production costs. When processing materials have high melting points or high hardness, it is necessary to face high-temperature wear problems; conventional steel tools are difficult to meet the requirements of this application. How to improve the high-temperature wear resistance of the stir tools is a key issue.

Funding: This research received no external funding.

Acknowledgments: We thank LetPub (www.letpub.com) for its linguistic assistance during the preparation of this manuscript.

Conflicts of Interest: The authors declare no conflict of interest.

\section{References}

1. Mishra, R.S.; Mahoney, M.W.; McFadden, S.X.; Mara, N.A.; Mukherjee, A.K. High strain rate superplasticity in a friction stir processed $7075 \mathrm{Al}$ alloy. Scr. Mater. 1999, 42, 163-168. [CrossRef]

2. Mishra, R.S.; Ma, Z.Y. Friction stir welding and processing. Mater. Sci. Eng. R Rep. 2005, 50, 1-78. [CrossRef] 
3. Ma, Z.Y. Friction stir processing technology: A review. Metall. Mater. Trans. A Phys. Metall. Mater. Sci. 2008, 39, 642-658. [CrossRef]

4. Padhy, G.K.; Wu, C.S.; Gao, S. Friction stir based welding and processing technologies-Processes, parameters, microstructures and applications: A review. J. Mater. Sci. Technol. 2018, 34, 1-38. [CrossRef]

5. Tamadon, A.; Pons, D.J.; Sued, K.; Clucas, D. Development of metallographic etchants for the microstructure evolution of A6082-T6 BFSW welds. Metals 2017, 7, 423. [CrossRef]

6. Xin, R.L.; Zheng, X.; Liu, Z.; Liu, D.; Qiu, R.S.; Li, Z.Y.; Liu, Q. Microstructure and texture evolution of an Mg-Gd-Y-Nd-Zr alloy during friction stir processing. J. Alloy. Compd. 2016, 659, 51-59. [CrossRef]

7. Wang, L.Q.; Xie, L.C.; Lv, Y.T.; Zhang, L.C.; Chen, L.Y.; Meng, Q.; Qu, J.; Zhang, D.; Lu, W.J. Microstructure evolution and superelastic behavior in Ti-35Nb-2Ta-3Zr alloy processed by friction stir processing. Acta Mater. 2017, 131, 499-510. [CrossRef]

8. Wang, Y.B.; Huang, Y.X.; Meng, X.C.; Wan, L.; Feng, J.C. Microstructural evolution and mechanical properties of Mg-Zn-Y-Zr alloy during friction stir processing. J. Alloy. Compd. 2017, 696, 875-883. [CrossRef]

9. Tamadon, A.; Pons, D.J.; Sued, K.; Clucas, D. Thermomechanical grain refinement in AA6082-T6 thin plates under bobbin friction stir welding. Metals 2018, 8, 375. [CrossRef]

10. Yang, Q.; Xiao, B.L.; Ma, Z.Y.; Chen, R.S. Achieving high strain rate superplasticity in Mg-Zn-Y-Zr alloy produced by friction stir processing. Scr. Mater. 2011, 65, 335-338. [CrossRef]

11. Oh-Ishi, K.; McNelley, T.R. The influence of friction stir processing parameters on microstructure of as-cast NiAl bronze. Metall. Mater. Trans. A Phys. Metall. Mater. Sci. 2005, 36A, 1575-1585. [CrossRef]

12. Navaser, M.; Atapour, M. Effect of friction stir processing on pitting corrosion and intergranular attack of 7075 aluminum alloy. J. Mater. Sci. Technol. 2017, 33, 155-165. [CrossRef]

13. Khodabakhshi, F; Gerlich, A.P.; Svec, P. Fabrication of a high strength ultra-fine grained Al-Mg-SiC nanocomposite by multi-step friction-stir processing. Mater. Sci. Eng. A Struct. Mater. Prop. Microstruct. Process. 2017, 698, 313-325. [CrossRef]

14. Sathiskumar, R.; Murugan, N.; Dinaharan, I.; Vijay, S.J. Role of friction stir processing parameters on microstructure and microhardness of boron carbide particulate reinforced copper surface composites. Sadhana Acad. Proc. Eng. Sci. 2013, 38, 1433-1450. [CrossRef]

15. Tamadon, A.; Pons, D.J.; Sued, K.; Clucas, D. Formation mechanisms for entry and exit defects in bobbin friction stir welding. Metals 2018, 8, 33. [CrossRef]

16. Sun, P.; Wang, K.; Wang, W.; Zhang, X. Influence of process parameter on microstructure of AZ31 magnesium alloy in friction stir processing. Hot Work. Technol. 2008, 37, 99. (In Chinese)

17. Barmouz, M.; Givi, M.K.B.; Seyfi, J. On the role of processing parameters in producing $\mathrm{Cu} / \mathrm{SiC}$ metal matrix composites via friction stir processing: Investigating microstructure, microhardness, wear and tensile behavior. Mater. Charact. 2011, 62, 108-117. [CrossRef]

18. Han, J.Y.; Chen, J.; Peng, L.M.; Zheng, F.Y.; Rong, W.; Wu, Y.J.; Ding, W.J. Influence of processing parameters on thermal field in Mg-Nd-Zn-Zr alloy during friction stir processing. Mater. Des. 2016, 94, 186-194. [CrossRef]

19. Jana, S.; Mishra, R.S.; Baumann, J.A.; Grant, G. Effect of process parameters on abnormal grain growth during friction stir processing of a cast $\mathrm{Al}$ alloy. Mater. Sci. Eng. A Struct. Mater. Prop. Microstruct. Process. 2010, 528, 189-199. [CrossRef]

20. Orozco-Caballero, A.; Ruano, O.A.; Rauch, E.F.; Carreno, F. Severe friction stir processing of an Al-Zn-Mg-Cu alloy: Misorientation and its influence on superplasticity. Mater. Des. 2018, 137, 128-139. [CrossRef]

21. Chen, C.F.; Kao, P.W.; Chang, L.W.; Ho, N.J. Effect of processing parameters on microstructure and mechanical properties of an $\mathrm{Al}-\mathrm{Al}_{11} \mathrm{Ce}_{3}-\mathrm{Al}_{2} \mathrm{O}_{3}$ in-situ composite produced by friction stir processing. Metall. Mater. Trans. A Phys. Metall. Mater. Sci. 2010, 41A, 513-522. [CrossRef]

22. Zohoor, M.; Givi, M.K.B.; Salami, P. Effect of processing parameters on fabrication of Al-Mg/Cu composites via friction stir processing. Mater. Des. 2012, 39, 358-365. [CrossRef]

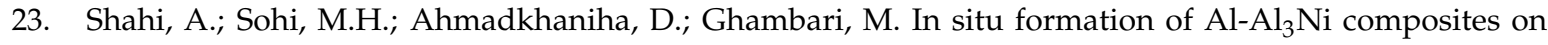
commercially pure aluminium by friction stir processing. Int. J. Adv. Manuf. Technol. 2014, 75, 1331-1337. [CrossRef]

24. Leal, R.M.; Galvao, I.; Loureiro, A.; Rodrigues, D.M. Effect of friction stir processing parameters on the microstructural and electrical properties of copper. Int. J. Adv. Manuf. Technol. 2015, 80, 1655-1663. [CrossRef] 
25. Mehta, K.P.; Badheka, V.J. Effects of tilt angle on the properties of dissimilar friction stir welding copper to aluminum. Mater. Manuf. Process. 2016, 31, 255-263. [CrossRef]

26. Ahmadkhaniha, D.; Sohi, M.H.; Zarei-Hanzaki, A. Optimisation of friction stir processing parameters to produce sound and fine grain layers in pure magnesium. Sci. Technol. Weld. Join. 2014, 19, 235-241. [CrossRef]

27. Khodabakhshi, F.; Gerlich, A.P.; Simchi, A.; Kokabi, A.H. Cryogenic friction-stir processing of ultrafine-grained $\mathrm{Al}-\mathrm{Mg}-\mathrm{TiO}_{2}$ nanocomposites. Mater. Sci. Eng. A Struct. Mater. Prop. Microstruct. Process. 2015, 620, 471-482. [CrossRef]

28. Chen, Y.; Ding, H.; Li, J.Z.; Cai, Z.H.; Zhao, J.W.; Yang, W.J. Influence of multi-pass friction stir processing on the microstructure and mechanical properties of Al-5083 alloy. Mater. Sci. Eng. A Struct. Mater. Prop. Microstruct. Process. 2016, 650, 281-289. [CrossRef]

29. Yang, R.; Zhang, Z.Y.; Zhao, Y.T.; Chen, G.; Guo, Y.H.; Liu, M.P.; Zhang, J. Effect of multi-pass friction stir processing on microstructure and mechanical properties of $\mathrm{Al}_{3} \mathrm{Ti} / \mathrm{A} 356$ composites. Mater. Charact. 2015, 106, 62-69. [CrossRef]

30. Khodabakhshi, F.; Arab, S.M.; Svec, P.; Gerlich, A.P. Fabrication of a new Al-Mg/graphene nanocomposite by multi-pass friction-stir processing: Dispersion, microstructure, stability, and strengthening. Mater. Charact. 2017, 132, 92-107. [CrossRef]

31. Zeidabadi, S.R.H.; Daneshmanesh, H. Fabrication and characterization of in-situ Al/Nb metal/intermetallic surface composite by friction stir processing. Mater. Sci. Eng. A Struct. Mater. Prop. Microstruct. Process. 2017, 702, 189-195. [CrossRef]

32. Adetunla, A.; Akinlabi, E. Mechanical characterization of Al/Ti-6Al-4V surface composite fabricated via FSP: A comparison of tool geometry and number of passes. Mater. Res. Express 2018, 5, 13. [CrossRef]

33. Costa, M.I.; Verdera, D.; Vieira, M.T.; Rodrigues, D.M. Surface enhancement of cold work tool steels by friction stir processing with a pinless tool. Appl. Surf. Sci. 2014, 296, 214-220. [CrossRef]

34. Mahmoud, E.R.I.; Takahashi, M.; Shibayanagi, T.; Ikeuchi, K. Effect of friction stir processing tool probe on fabrication of SiC particle reinforced composite on aluminium surface. Sci. Technol. Weld. Join. 2009, 14, 413-425. [CrossRef]

35. Qian, J.; Li, J.; Xiong, J.; Zhang, F.; Lin, X. In-situ synthesized Al3Ti-Al surface composites by friction stir processing. Trans. China Weld. Inst. 2010, 31, 61-64.

36. Sathiskumar, R.; Murugan, N.; Dinaharan, I.; Vijay, S.J. Characterization of boron carbide particulate reinforced in situ copper surface composites synthesized using friction stir processing. Mater. Charact. 2013, 84, 16-27. [CrossRef]

37. Hosseini, S.A.; Ranjbar, K.; Dehmolaei, R.; Amirani, A.R. Fabrication of Al5083 surface composites reinforced by CNTs and cerium oxide nano particles via friction stir processing. J. Alloy. Compd. 2015, 622, 725-733. [CrossRef]

38. Sahraeinejad, S.; Izadi, H.; Haghshenas, M.; Gerlich, A.P. Fabrication of metal matrix composites by friction stir processing with different Particles and processing parameters. Mater. Sci. Eng. A Struct. Mater. Prop. Microstruct. Process. 2015, 626, 505-513. [CrossRef]

39. Srinivasu, R.; Rao, A.S.; Reddy, G.M.; Rao, K.S. Friction stir surfacing of cast A356 aluminium-silicon alloy with boron carbide and molybdenum disulphide powders. Def. Technol. 2015, 11, 140-146. [CrossRef]

40. Ahmadkhaniha, D.; Fedel, M.; Sohi, M.H.; Hanzaki, A.Z.; Deflorian, F. Corrosion behavior of magnesium and magnesium-hydroxyapatite composite fabricated by friction stir processing in Dulbecco's phosphate buffered saline. Corros. Sci. 2016, 104, 319-329. [CrossRef]

41. Garcia-Bernal, M.A.; Mishra, R.S.; Verma, R.; Hernandez-Silva, D. Influence of friction stir processing tool design on microstructure and superplastic behavior of Al-Mg alloys. Mater. Sci. Eng. A Struct. Mater. Prop. Microstruct. Process. 2016, 670, 9-16. [CrossRef]

42. Patel, V.V.; Badheka, V.J.; Kumar, A. Influence of pin profile on the tool plunge stage in friction stir processing of Al-Zn-Mg-Cu alloy. Trans. Indian Inst. Met. 2017, 70, 1151-1158. [CrossRef]

43. Mishra, R.S.; Ma, Z.Y.; Charit, I. Friction stir processing: A novel technique for fabrication of surface composite. Mater. Sci. Eng. A Struct. Mater. Prop. Microstruct. Process. 2003, 341, 307-310. [CrossRef]

44. Khodabakhshi, F.; Marzbanrad, B.; Jahed, H.; Gerlich, A.P. Interfacial bonding mechanisms between aluminum and titanium during cold gas spraying followed by friction-stir modification. Appl. Surf. Sci. 2018, 462, 739-752. [CrossRef] 
45. Yang, K.; Li, W.Y.; Niu, P.L.; Yang, X.W.; Xu, Y.X. Cold sprayed AA2024/ $\mathrm{Al}_{2} \mathrm{O}_{3}$ metal matrix composites improved by friction stir processing: Microstructure characterization, mechanical performance and strengthening mechanisms. J. Alloy. Compd. 2018, 736, 115-123. [CrossRef]

46. Maamoun, A.H.; Veldhuis, S.C.; Elbestawi, M. Friction stir processing of AlSi10Mg parts produced by selective laser melting. J. Mater. Process. Technol. 2019, 263, 308-320. [CrossRef]

47. Reddy, G.M.; Rao, A.S.; Rao, K.S. Friction stir surfacing route: effective strategy for the enhancement of wear resistance of titanium alloy. Trans. Indian Inst. Met. 2013, 66, 231-238. [CrossRef]

48. Reddy, G.M.; Rao, A.S.; Rao, K.S. Friction stir processing for enhancement of wear resistance of ZM21 magnesium alloy. Trans. Indian Inst. Met. 2013, 66, 13-24. [CrossRef]

49. Huang, Y.; Wang, T.; Lu, S.; Liu, H.; Ao, F. A novel method of in-situ fabrication of Mg surface composites by friction stir process. Trans. China Weld. Inst. 2013, 34, 25-28. (In Chinese)

50. Sekban, D.M.; Aktarer, S.M.; Yanar, H.; Alsaran, A.; Purcek, G. Improvement the wear behavior of low carbon steels by friction stir processing. IOP Conf. Ser. 2017, 174, 012058. [CrossRef]

51. Tinubu, O.O.; Das, S.; Dutt, A.; Mogonye, J.E.; Ageha, V.; Xu, R.; Forsdike, J.; Mishra, R.S.; Scharf, T.W. Friction stir processing of A-286 stainless steel: Microstructural evolution during wear. Wear 2016, 356-357, 94-100. [CrossRef]

52. Pang, J.J.; Liu, F.C.; Liu, J.; Tan, M.J.; Blackwood, D.J. Friction stir processing of aluminum alloy AA7075: Microstructure, surface chemistry and corrosion resistance. Corros. Sci. 2016, 106, 217-228. [CrossRef]

53. Kawasaki, M.; Langdon, T.G. Principles of superplasticity in ultrafine-grained materials. J. Mater. Sci. 2007, 42, 1782-1796. [CrossRef]

54. Ruano, O.A.; Sherby, O.D. On constitutive-equations for various diffusion-controlled creep mechanisms. Revue De Physique Appliquee 1988, 23, 625-637. [CrossRef]

55. Carreño, F.; Orozco-Caballero, A. Superplastic GBS Constitutive equation incorporating average grain misorientation dependence. Mater. Sci. Forum 2018, 941, 1501-1506. [CrossRef]

56. Zhang, W.J.; Ding, H.; Cai, M.H.; Yang, W.J.; Li, J.Z. Ultra-grain refinement and enhanced low-temperature superplasticity in a friction stir-processed Ti-6Al-4V alloy. Mater. Sci. Eng. A Struct. Mater. Prop. Microstruct. Process. 2018, 727, 90-96. [CrossRef]

57. Charit, I.; Mishra, R.S. High strain rate superplasticity in a commercial 2024 Al alloy via friction stir processing. Mater. Sci. Eng. A Struct. Mater. Prop. Microstruct. Process. 2003, 359, 290-296. [CrossRef]

58. Ma, Z.Y.; Mishra, R.S.; Mahoney, M.W. Superplasticity in cast A356 induced via friction stir processing. Scr. Mater. 2004, 50, 931-935. [CrossRef]

59. Johannes, L.B.; Mishra, R.S. Multiple passes of friction stir processing for the creation of superplastic 7075 aluminum. Mater. Sci. Eng. A Struct. Mater. Prop. Microstruct. Process. 2007, 464, 255-260. [CrossRef]

60. Ma, Z.Y.; Liu, F.C.; Mishra, R.S. Superplastic deformation mechanism of an ultrafine-grained aluminum alloy produced by friction stir processing. Acta Mater. 2010, 58, 4693-4704. [CrossRef]

61. Xie, G.M.; Luo, Z.A.; Ma, Z.Y.; Xue, P.; Wang, G.D. Superplastic behavior of friction stir processed ZK60 magnesium alloy. Mater. Trans. 2011, 52, 2278-2281. [CrossRef]

62. Chai, F.; Zhang, D.T.; Li, Y.Y.; Zhang, W.W. High strain rate superplasticity of a fine-grained AZ91 magnesium alloy prepared by submerged friction stir processing. Mater. Sci. Eng. A Struct. Mater. Prop. Microstruct. Process. 2013, 568, 40-48. [CrossRef]

63. Karthikeyan, L.; Kumar, V.S.S.; Padmanabhan, K.A. Investigations on superplastic forming of friction stir-processed AA6063-T6 aluminum alloy. Mater. Manuf. Process. 2013, 28, 294-298. [CrossRef]

64. Cao, G.H.; Zhang, D.T.; Chai, F.; Zhang, W.W.; Qiu, C. Superplastic behavior and microstructure evolution of a fine-grained Mg-Y-Nd alloy processed by submerged friction stir processing. Mater. Sci. Eng. A Struct. Mater. Prop. Microstruct. Process. 2015, 642, 157-166. [CrossRef]

65. Zhao, Y.T.; Kai, X.Z.; Chen, G.; Lin, W.L.; Wang, C.M. Effects of friction stir processing on the microstructure and superplasticity of in situ nano-ZrB2/2024Al composite. Prog. Nat. Sci. 2016, 26, 69-77. [CrossRef]

66. Orozco-Caballero, A.; Alvarez-Leal, M.; Hidalgo-Manrique, P.; Cepeda-Jimenez, C.M.; Ruano, O.A.; Carreno, F. Grain size versus microstructural stability in the high strain rate superplastic response of a severely friction stir processed Al-Zn-Mg-Cu alloy. Mater. Sci. Eng. A Struct. Mater. Prop. Microstruct. Process. 2017, 680, 329-337. [CrossRef] 
67. Yang, Y.G.; Zhao, Y.T.; Kai, X.Z.; Tao, R. Superplasticity behavior and deformation mechanism of the in-situ Al3Zr/6063Al composites processed by friction stir processing. J. Alloy. Compd. 2017, 710, $225-233$. [CrossRef]

68. Jiao, L.; Yang, Y.G.; Li, H.; Zhao, Y.T.; Wang, X.L. Effects of plastic deformation on microstructure and superplasticity of the in situ AI(3)Ti/2024AI composites. Mater. Res. Express 2018, 5, 13. [CrossRef]

69. Ahmadkhaniha, D.; Sohi, M.H.; Salehi, A.; Tahavvori, R. Formations of $\mathrm{AZ} 21 / \mathrm{Al}_{2} \mathrm{O}_{3}$ nano-composite layer by friction stir processing. J. Magnes. Alloy. 2016, 4, 314-318. [CrossRef]

70. Mahmoud, E.R.I.; Tash, M.M. Characterization of aluminum-based-surface matrix composites with iron and iron oxide fabricated by friction stir processing. Materials 2016, 9, 505. [CrossRef]

71. Kim, J.Y.; Hwang, J.W.; Kim, H.Y.; Lee, S.M.; Jung, W.S.; Byeon, J.W. Fabrication of AZ31/CNT surface nano-composite by double-pass friction stir processing. Arch. Metall. Mater. 2017, 62, 1039-1042. [CrossRef]

72. Moustafa, E. Effect of multi-pass friction stir processing on mechanical properties for $\mathrm{AA} 2024 / \mathrm{Al}_{2} \mathrm{O}_{3}$ nanocomposites. Materials 2017, 10, 1053. [CrossRef] [PubMed]

73. Fernandez, J.B.; Macias, E.J.; Muro, J.; Caputi, L.S.; Miriello, D.; De Luca, R.; Roca, A.S.; Fals, H.D.C. Tribological behavior of AA1050H24-graphene nanocomposite obtained by friction stir processing. Metals 2018, 8, 113. [CrossRef]

74. Parumandla, N.; Adepu, K. Effect of $\mathrm{Al}_{2} \mathrm{O}_{3}$ and $\mathrm{SiC}$ nano reinforcements on microstructure, mechanical and wear properties of surface nanocomposites fabricated by friction stir processing. Mater. Sci. Medzg. 2018, 24, 338-344. [CrossRef]

75. Zhu, C.Y.; Lv, Y.T.; Qian, C.; Ding, Z.H.; Jiao, T.; Gu, X.Y.; Lu, E.Y.; Wang, L.Q.; Zhang, F.Q. Microstructures, mechanical, and biological properties of a novel Ti-6V-4V/zinc surface nanocomposite prepared by friction stir processing. Int. J. Nanomed. 2018, 13, 1881-1898. [CrossRef] [PubMed]

76. Tjong, S.C.; Ma, Z.Y. Microstructural and mechanical characteristics of in situ metal matrix composites. Mater. Sci. Eng. R Rep. 2000, 29, 49-113. [CrossRef]

77. Hsu, C.J.; Kao, P.W.; Ho, N.J. Ultrafine-grained $\mathrm{Al}-\mathrm{Al}_{2} \mathrm{Cu}$ composite produced in situ by friction stir processing. Scr. Mater. 2005, 53, 341-345. [CrossRef]

78. Qian, J.W.; Li, J.L.; Xiong, J.T.; Zhang, F.S.; Lin, X. In situ synthesizing $\mathrm{Al}_{3} \mathrm{Ni}$ for fabrication of intermetallic-reinforced aluminum alloy composites by friction stir processing. Mater. Sci. Eng. A Struct. Mater. Prop. Microstruct. Process. 2012, 550, 279-285. [CrossRef]

79. You, G.L.; Ho, N.J.; Kao, P.W. The microstructure and mechanical properties of an Al-CuO in-situ composite produced using friction stir processing. Mater. Lett. 2013, 90, 26-29. [CrossRef]

80. You, G.L.; Ho, N.J.; Kao, P.W. Aluminum based in situ nanocomposite produced from Al-Mg-CuO powder mixture by using friction stir processing. Mater. Lett. 2013, 100, 219-222. [CrossRef]

81. Hsu, C.J.; Kao, P.W.; Ho, N.J. Intermetallic-reinforced aluminum matrix composites produced in situ by friction stir processing. Mater. Lett. 2007, 61, 1315-1318. [CrossRef]

82. Madhu, H.C.; Kailas, S.V. In-situ aluminothermal reduction synthesis of $\mathrm{Ti}_{3} \mathrm{AlC}_{2}$ aluminium composite by friction stir processing. Procedia Manuf. 2016, 7, 157-162. [CrossRef]

83. Rajan, H.B.M.; Dinaharan, I.; Ramabalan, S.; Akinlabi, E.T. Influence of friction stir processing on microstructure and properties of AA7075/TiB2 in situ composite. J. Alloy. Compd. 2016, 657, 250-260. [CrossRef]

(C) 2019 by the authors. Licensee MDPI, Basel, Switzerland. This article is an open access article distributed under the terms and conditions of the Creative Commons Attribution (CC BY) license (http://creativecommons.org/licenses/by/4.0/). 